\title{
CLEAN PRODUCTION IN UKRAINE: STATE AND PROSPECTS
}

\author{
V. P. STADNYK, Ph. D. Economics, Senior Lecturer the Department \\ of management A separate division of National University of Life and \\ Environmental Sciences of Ukraine of the "Nizhyn Agrotechnical Institute» \\ ORCID 0000-0003-3154-3983 \\ Nizhyn Agrotechnical Institute of the National University of Life \\ and Environmental Sciences of Ukraine \\ E-mail:vika_stadnyk@ukr.net \\ O. V. CHETVERYK, Ph. D. Economics, Associate Professor Department \\ of Marketing and International Trade \\ National University of Life and Environmental Sciences of Ukraine \\ ORCID 0000-0001-7573-0874 \\ E-mail: ChetverykOlena@gmail.com
}

\begin{abstract}
Анотація. In the article the current state of the production of ecologically clean products in Ukraine made an analysis of the major publications on the topic. It is established that the purpose of this research is a study based on the analysis of land resources in the process of their economic use of their key role in ensuring the safety of agrifood sector. The paper considers the extent of production and implementation of environmentally friendly products and the need for an increase in its volume. Highlight main directions of production organization on environmental principles, on the basis of planning of agricultural production on the ecological basis of including appropriate successive stages. Conditions the dynamics of indexes of production of ecologically clean products in Ukraine and on the example of agricultural enterprises. Based on the environmentally sound production of agricultural products defined formation and practical realization of the economic mechanism of stimulation of the production of environmentally friendly products. The development of agricultural enterprises, based on the production and implementation of environmentally-friendly products can be achieved due to the vertical integration of the enterprises working in the market of environmentally friendly products and United in Ukrainian financial group with the active participation of Government support, increasing the competitiveness of the agricultural enterprises entering the international markets, enhance the economic potential of agriculture, the project development certification environmental products according to international standards.
\end{abstract}

Ключові слова: clean production, cleaner production, greening, organic agriculture. 


\section{Introduction.}

In the domestic and foreign literature is paid much attention to the issues of cleaner production. Basic scientists who studied this problem in their writings are: A. Vdovichenko, V. Vlasov, S. Illjashenko, S. Hominy, 1. Melnyk, V. Shlapak and others. Among the foreign scientists can distinguish R. Aleksahìna, A. Golubeva, L. Dobiša and others.

Leaders in applying the strategy of ecologically clean production have become countries of Central and Eastern Europe. This strategy is capable of forming a system of principles and mechanisms for environmentally sound production and comprehensively tackle the environmental and economic problems.

Purpose. Is the study of the condition of the production of environmentally friendly products as preconditions for increasing the competitiveness of crop and livestock production and profitability management.

\section{Methods.}

Methodological and informational Foundation work is scientific papers, periodicals, Internet resources, regulations and international standards.

The theoretical and methodological basis of the research is the systematic approach to the study of economic objects, phenomena and processes, their key problems and solutions.

\section{Results.}

The practice of intensive maintenance of agriculture caused a violation of the ecological balance of nature: the accumulation of toxic substances in the soil, increased erosion, as a result, unsatisfactory quality and safety of locally grown products. To resolve the issue of the protection of agro-landscapes and to ensure the competitiveness of agricultural products can be through the development of environmental technologies for the production of organic products.

The question of safe and high-quality food has become relevant in international trade the past 10-15 years. Environmental safety and quality of products in modern conditions are the main factors of internal and external first competitiveness. The EU leaders in the production and sales of environmentally friendly products are Germany, United Kingdom, Switzerland, Denmark, Finland, where $6-12 \%$ of farms using innovative production technology.

Currently, about $24 \%$ of Austrian agriculture-ecological clean and in some lands, it reaches $50 \%$. Denmark expects to achieve similar goals to the year 2016 . In the UK is generally the only growing sector. There successfully operates about 600 organic farms. The volume of sales of products of organic farming, back in 2000, was estimated at 300 million. dollars, it is estimated that by 2016, this figure will increase to 9 times. In Swiss agriculture, the proportion of organic farming is about $10 \%$, and of alternative farms reaches $5 \%$ of the total number of users [3].

The feature of the market of organic products is a constant growth in demand and increasing prices $20-50 \%$, unlike the traditional market. So, among the countries of Europe to select leaders for the average cost of the consumption of environmentally friendly products in per capita as Switzerland (103 euros), Sweden (47 euros), Germany (38 euros), France and the United Kingdom (27 euros). The main European distribution channels for organic products is a chain of retail trade (70\%); direct sales from businesses and sales through markets, which provide ap- 
proximately $15 \%$ of sales; sales through specialty stores up to $15 \%$ on average, Buyers. are overpaid for organic products $40-60 \%$ [6, 87-88].

The main forms of support to organic farming in the European Union there are grants for programs for rural development, legal protection of producers, national plans of action. European action plan on the introduction of the production of organic food and agriculture provides, say, carrying out information campaigns in order to raise awareness about organic agriculture farming.

In Ukraine, the only legislative document regulating the rules and norms of production of environmentally friendly products is the Law of Ukraine «On production and circulation of organic agricultural products and raw materials» from 03.09.2013, № 425-VII. According to this law, organic raw materials and products should be produced in certain areas for conducting organic agricultural production.

Produced products are intended for consumption in recycled or non-processed form, in its composition has biologically valuable qualities and properties. For the practical functioning of the economic mechanism of stimulating production of environmentally friendly products It is worth accepting the laws «On ecological agricultural production and its labeling on agricultural products and products» «On Ecological Farming», «On certification of organic products», etc.

In General, economic stimulation of the production of environmentally friendly products is based on the installation of tax, price, credit, customs and other attempts for agricultural commodity producers, which implement ecologically clean and harmless, Competitive products in the simultaneous implementation of non-waste, resource-saving production.
According to the official data of the Organic Business Handbook of Ukraine in 2014, 182 certified organic farms were registered, and in 2017 this figure increased to 224 farms. The Total area of certified organic agricultural lands in 2014-400, 764 thous. hectares, and in 2017, 493.248 thous. A positive dynamic is 92.502 thous. hectares [5, pp. 274-275].

The Share of certified organic areas among the total volume of agricultural lands of Ukraine is about $1 \%$. In this case, Ukraine occupies the first place in the Eastern European region on the certified area of organic arable industry, specializing mainly in the production of cereals, legumes and oilseeds [1, pp. 115-116].

The Main areas of promotion are expedient to consider the following steps: The increased size of payments to purchasing prices up to $60-65 \%$ on ecologically clean products; The surcharge shall be carried out for all products made by environmentally safe technologies, which meets international quality standards; Organic products are obliged to spread throughout the consumer market, not on the separate sectors.

In Ukraine expand plantings of organic crops, mostly corn. The leaders - the economy of Vinnytsia (PE «Melnik»), Poltava (PP «Agroecology»), Kherson (PE Makharshi), Zhytomyr (LLC «Galeks-agro»), Chernihiv (Group of companies «Etnoprodukt») and others.

Research of problems of functioning of the world and domestic markets of organic food products allowed to allocate the following factors that inhibit the development of organic technologies in Ukraine: active support of ecological agriculture in $\mathrm{Eu}$ countries; Lack of state support of organic food production in Ukraine; Lack of material incentives for conversion of agricultural production; Absence of a system of state 
certification of organic products; Lack of activity to clarify citizens the importance of production and consumption of organic food to preserve the production and consumption of organic food products for preserving and restoring health and environment.

It is worth noting that the main organization on environmental principles, on the basis of planning of agricultural production on the ecological basis including the successive stages (fig. 2).

Acetalization with the implementation of ecological orientation of agricultural production lays the foundations to diversify the ways to shift the pace of production of eco products with the involvement of eco-technologies in agriculture, search for new forms and Management methods that can minimize negative impact on the production of agricultural products on the environment.

\section{Discussion.}

During the study it was established that on the basis of greening of agricultural products the formation and practical realization of the economic mechanism of stimulation of ecologically pure production Is defined. Development of agricultural enterprises on the basis of production and sale of environmentally friendly products can be achieved by means of vertical integration of enterprises, working in the market of environmentally friendly goods and joint in agro-industrial Financial Group with active participation of state support, increase of competitive capacity of agricultural enterprises, entering international markets, increasing economic potential of the region, agricultural sector, project development Environmental product Certification According to European requirements and standards.

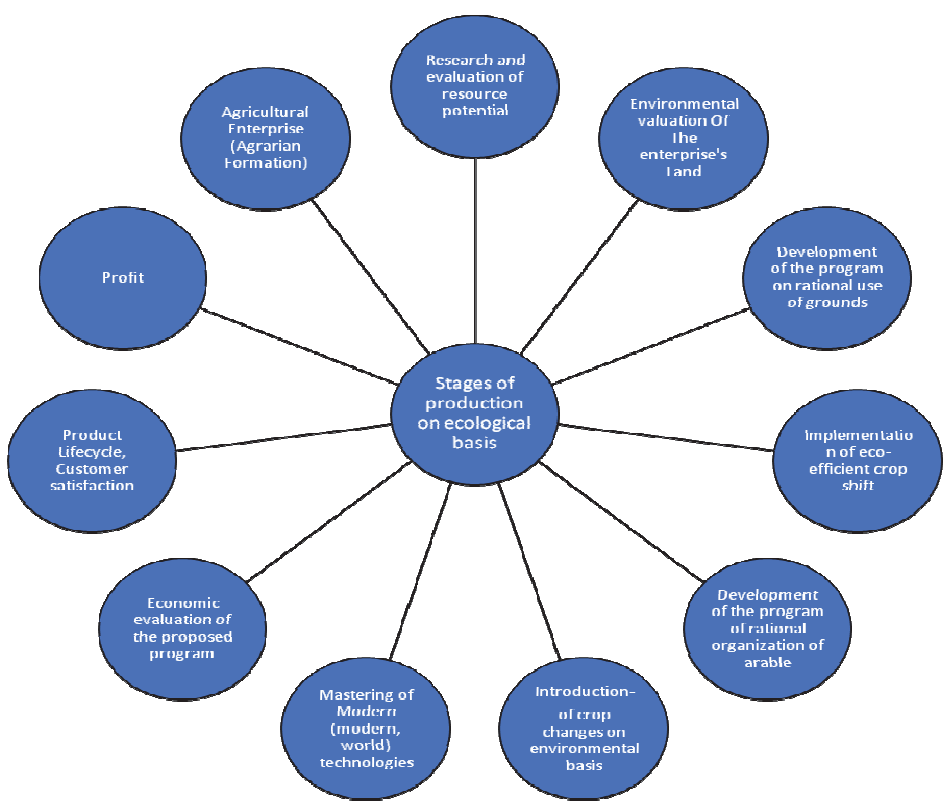

Fig. 2 Stages of organization of agricultural production on ecological basis

Note. Authoring 


\section{References}

1. Artash V. I., Artichoke V. I. (2010) Development of the world market of organic products. Economy of AIC, 113-116.

2. Eliaeva N. V., Belyanevych N. V. (2013) Modern State of production of organic products in Ukraine and the World. Innovation economy, 1 : 151-155.

3. Zhuravy S. V., Matviychuk B., Matviychuk N. G. (2011) Features of organic farming in Polissya. Collection of scientific papers of NSC «Institute of Agriculture of the NSSR»|, 1-2:8694. Available at: http://agrikalture.kiev.ua/ wp-content/uploads/2011/04/13. pdf
4. Kapshtyk M. V. (2012) Normative-Legal support of organic production in Ukraine: Problems and Perspectives. Agroecological journal, $1:$ 25-31.

5. Mamalyha S. V., Hluknybok O. P. (2012) Development of the market of organic products in Ukraine. Collection Of Scientific Works of Tavria State Agrotechnological University, 2 (28) : 270-279.

6. Shishka I. B. (2012) Production of ecologically clean agricultural products in Ukraine. Scientific researches and their practical application. Modern State and ways of development, 2-12: 86-93.

\section{В. П. Стадник (2019). Екологічно чиста продукція в Україні: стан}

та перспективи. БІОЕКОНОНОМІКА ТА АГРАРНИЙ БІЗНЕС, 10(1): 106-111.

http://doi.org//10.31548/bioeconomy2019.01.106

Анотація. У статті розглянуто сучасний стан виробничтва екологічно чистої продукції в Україні. Зроблено аналіз основних публікацій з даної теми. Встановлено, що метою даного дослідження $\epsilon$ обгрунтування на основі налізу функцій земельних ресурсів у процесі їх господарського використання їх ключові ролі в гарантуванні безпеки агропродовольчої срери. Розглянуто ступінь виробництва і реалізації, екологічно чистих продуктів та необхідність збільшення його обсягів. Виділено основні напрями організації виробництва на екологічних засадах, на засадах планування сільськогосподарського виробництва на екологічній основі включаючи відповідні послідовні етапи. Прогнозовано динаміку показників виробництва екологічно чистої продукції в Україні та на прикладі сільськогосподарського підприємства. На основі екологізації виробництва аграрної продукції визначено формування та практичну реалізацію економічного механізму стимулювання виробництва екологічно чистої продукції.

Ключові слова: екологічно чиста продукція, екологічно чисте виробництво, органічне сільське господарство.

В. П. Стадник, Е. В. Четверик (2019). Экологически чистая продукция в Украине: состояние и перспективы. БІОЕКОНОНОМІКА ТА АГРАРНИЙ БІЗНЕС, 10(1): 106-111. http://doi.org//10.31548/bioeconomy2019.01.106

Аннотация. В статье рассмотрено современное состояние производства экологически чистой продукции в Украине. Сделан анализ основных публикаций по данной теме. Установлено, что целью данного исследования является обоснование на основе налезет функций земельных ресурсов в процессе их хозяйственного использо- 
вания ключевые роли в обеспечении безопасности агропродовольственной сферы. Рассмотрены степень производства и реализации экологически чистых продуктов и необходимость увеличения его объемов. Выделены основные направления организации производства на экологических принципах, на основе планирования сельскохозяйственного производства на экологической основе включая соответствующие последовательные этапы. Прогнозируемо динамику показателей производства экологически чистой продукции в Украине и на примере сельскохозяйственного предприятия. На основе экологизации производства аграрной продукции определено формирование и практическую реализацию экономического механизма стимулирования производства экологически чистой продукции.

Ключевые слова: экологически чистая продукция, экологически чистое производство, органическое сельское хозяйство. 